\title{
FINANCIAL MARKETS IN RUSSIA IN MARCH 2013
}

\author{
N.Andrievsky. E.Khudko
}

The stock market dynamics in March was affected by several developments, such as a decrease in oil futures prices and the crisis situation in Cyprus. From the beginning of the month the growth was replaced by a reverse trend. The dynamics of stock market indices has led to a decrease in capitalization by $4.66 \%$. The situation in the Russian domestic corporate bond market remained stable. In general, in March the volume and market index were growing, and the activity of issuers and investors in the primary and secondary market segments remained at a high level. A negative factor was the increased weighted average yield and a record number of canceled bond issues because of non-placement of any security.

\section{Russian stock market basic structural indices dynamics}

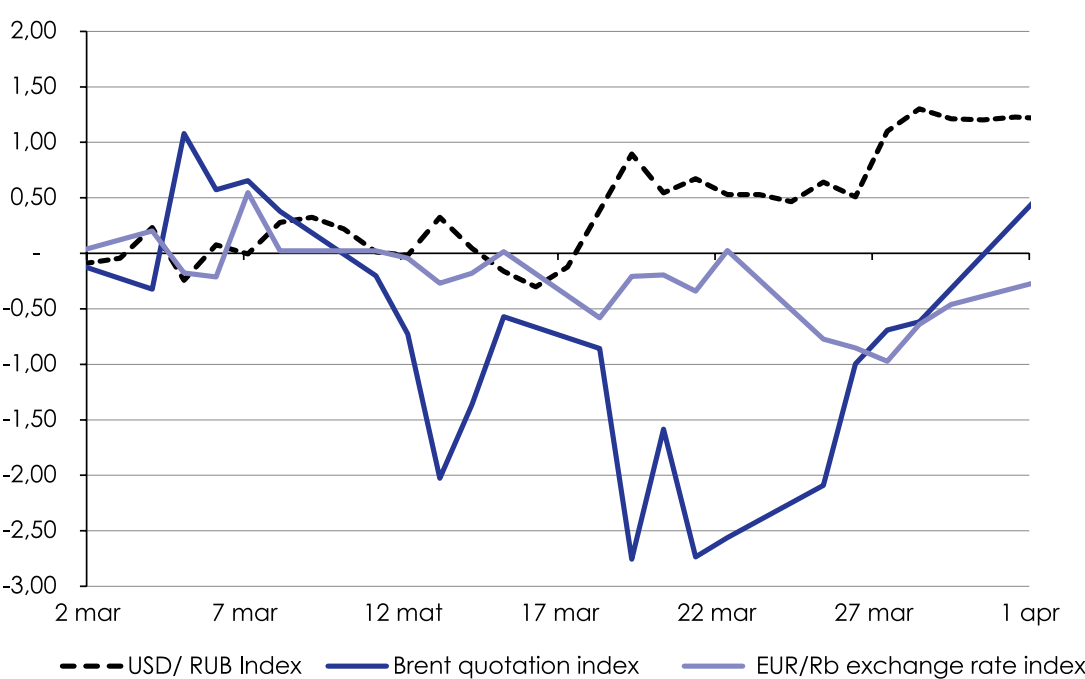

Source: RBC quote, authors' estimates.

Fig. 1. Dynamics of the dollar and Euro indices and Brent oil quotations

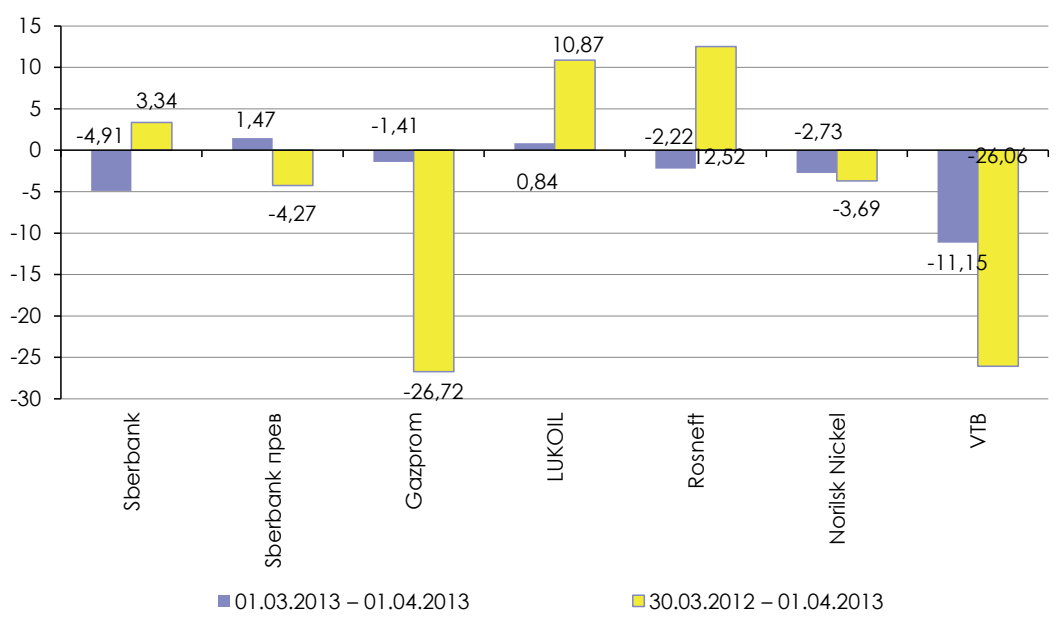

Source: RBC quote, authors' estimates.

Fig. 2. Growth rates of quotations of highly liquid securities at the MICEX in March of the current year (from March 1 to April 1) and from March 30, 2012 to April 1, 2013
In mid-March, the average futures price for Brent crude oil has decreased to $\$ 98.37 / \mathrm{bbl}$, which is by $4.95 \%$ lower than the relevant indicator in February of the current year. Dollar exchange rate throughout the month remained negatively correlated with oil price index and remained at $\mathrm{Rb} / \$ 30.61-31.10$, and at the end of March has slightly grown (Fig. 1). It is also necessary to note the absence of intervention in the foreign exchange market by the Bank of Russia. The value of the European currency against the Russian ruble fluctuated around $1 \%$ of the level of $\mathrm{Rb} 40$. Herewith, the depreciation of the Euro was provoked by the aggravation of the crisis situation in Cyprus, which provided a negative impact on the stock indices.

Since the beginning of the month, on March 12 the MICEX index has reached the maximum value of $2.07 \%$. However, the last days of the month were characterized by the end of the "rally" in the banking sector and the power industry, as well as lower stock index of chemical and engineering sectors, and all these factors led to the negative dynamics $(-3.06 \%)$, of the MICEX index in the monthly terms. In March, the leader of the rising 
cost among «blue chips» were the privileged shares of Sberbank (Fig. 2), at the end of the month the highest yield to investors on them was recorded at the level of $1.47 \%$. On the contrary, the ordinary Sberbank and VTB shares became the "leaders" of the month in terms of downgrading, the decline rates were $-4.91 \%$ and $-11.15 \%$, respectively. For investors who have invested in the "blue chips" a year ago, the most profitable were shares of Rosneft $(+12.52 \%$ on the same date of the last year.). Positive annual yield was sustained by the shares of Sberbank and LUKOIL - the yield was $3.34 \%$ and $10.87 \%$. In February, the annual yield on the shares of Sberbank was $7.67 \%$, and $6.2 \%$ on those of LUKOIL. Note that during the month the quotations dynamics was extremely volatile. The leader of growth in the first decade of the month was the sector of innovations, which demonstrated a moderate decline in January-February. In addition, at the end of the month indices of power, financial and banking sectors continued their decline, as well as the index of the mining industry with a negative yield up to $13 \%$ in the last week of the month. Recall that in December and January there was noted an increase of 5-6\% per month in these sectors, despite the fact that the MICEX index was growing at the rate of $3.2 \%$ per month.

The same situation as with the sectoral indices was observed in the index capitalization. Thus, the basic index capitalization ${ }^{1}$ before March 11 was stable, but then it started to decrease and by March 18 has declined by $4 \%$. This was mainly due to lower quotations of power sector companies' shares.

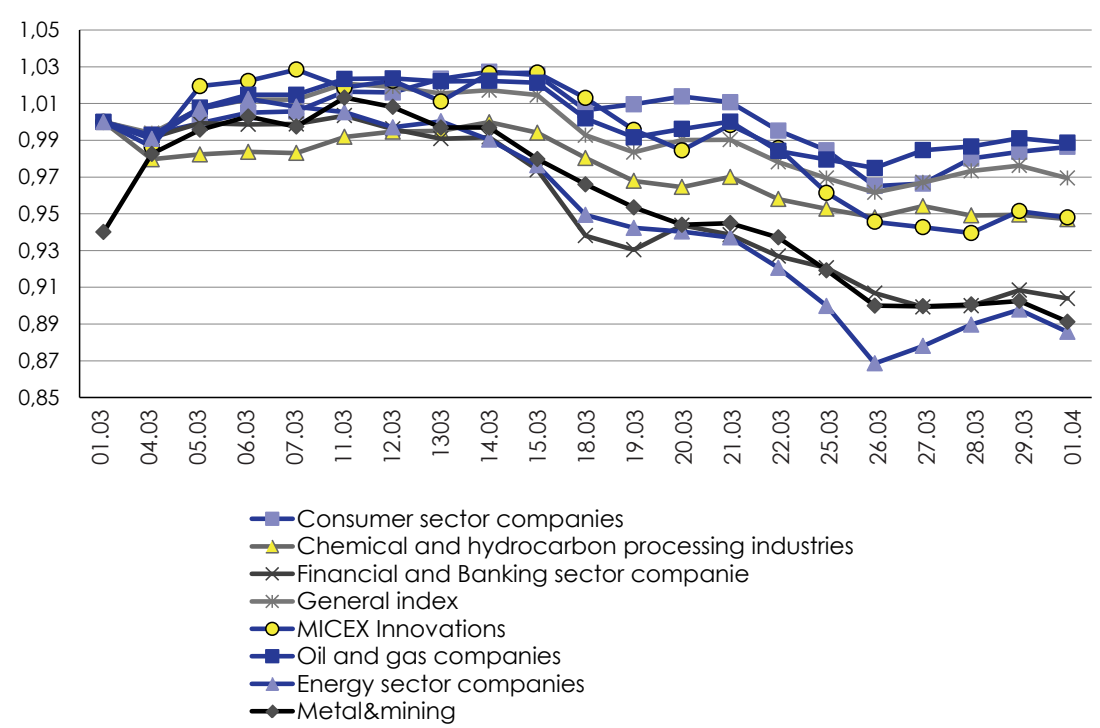

Source: RBC quote, author's estimates.

Fig. 3. MICEX stock indices growth rates

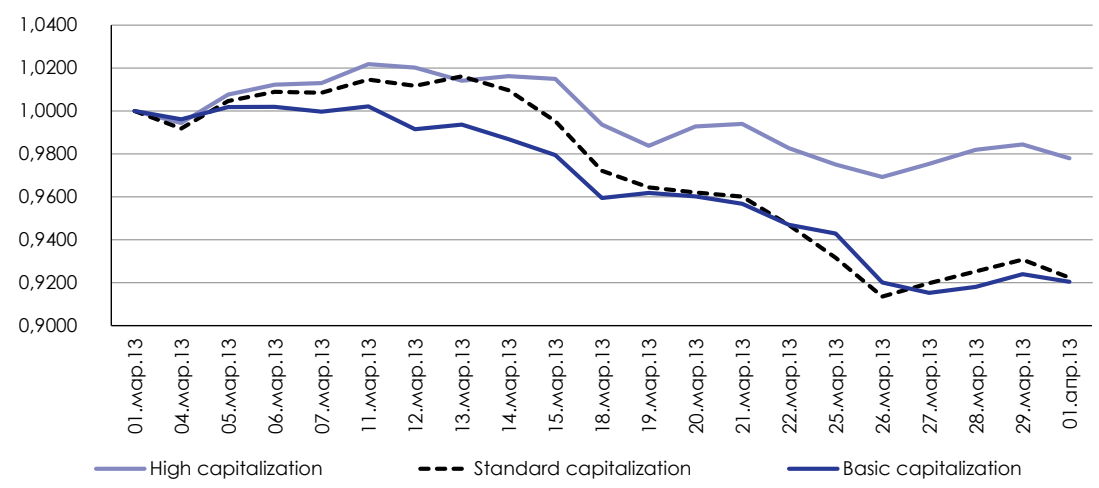

Source: RBC quote, authors' estimates.

Fig. 4. Dynamics of MICEX capitalization indices growth rates

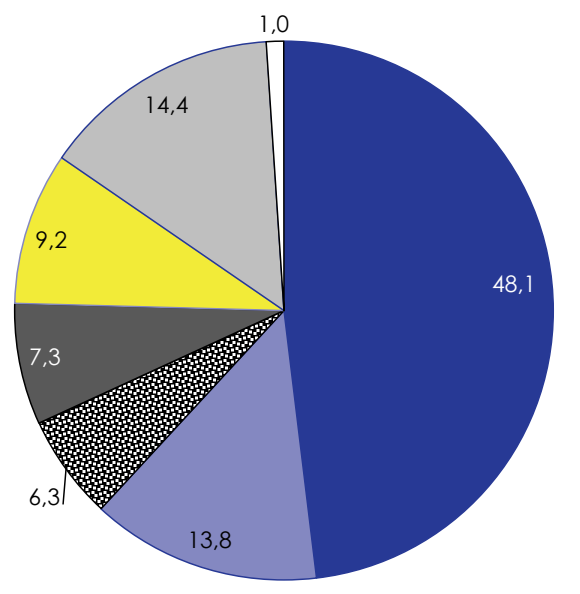

Mining operations
$\square$ Manufacturing industry
Energy, gas and water production and
distribution
$\square$ Wholesale and retail trade
$\square$ Transport and communications
$\square$ Financial activities
$\square$ Other activities

Source: MICEX official web-site, authors' estimates.

Fig. 5. The structure of the stock market capitalization as broken down by industries

1 Capitalization indices are price weighted by market capitalization indices of the most liquid stocks of the Russian issuers admitted to trading on ZAO "MICEX Stock Exchange", http://rts.micex.ru/s77 
Standard capitalization index has grown by $1.6 \%$ as of March 13 , but since it includes at most the companies of electric power and metallurgy industry producers, by the end of the month it declined to $92 \%$ of the March 1 indicator.

In March there were no offerings of any company, and capitalization of the stock exchange has decreased by $4.66 \%$ or Rb 1.17 trillion. Total capitalization of the Russian stock market on April 1, 2013 amounted to $\mathrm{Rb} 24.07$ trillion or $40.48 \%$ of GDP. The volatile rate of the shares price led to the following changes in the structure of the stock market capitalization by businesses: in March, the capitalization share of the companies engaged in wholesale and retail trade has grown by $0.4 \%$; the share of capitalization of transport and communication companies has increased by $1 \%$. The growth was based on the reduction of the shares of the mining sector $(-0.6 \%)$, production and distribution of power, gas and water $(-0.5 \%)$, and the financial sector $(-0.1 \%)$ in the stock market capitalization.

\section{Corporate bonds market}

In March the volume of domestic corporate bond market in Russia (at the nominal value of the securities in circulation, denominated in national currency) continued to grow at an accelerated rate and reached the level of $\mathrm{Rb} 4,408.3 \mathrm{bn}$, which is by $3.9 \%$ more than its indicator at the end of February (in the last few months the growth rate averaged 1.5-2.0\%) ${ }^{1}$. The growth of the market capacity once again was based on the number of bond loans (952 issues of corporate bonds registered in the national currency against 914 emissions at the end of the previous month), while the number of issuers represented in the debt segment for several months remained virtually unchanged (343 emitters against 338 emitters in February). There are also still several issues of bonds in U.S. dollars, and one issue in Japanese yen in circulation.

Investments in the secondary market for corporate bonds in March also significantly increased. Thus, from February 25 to March 25 the total volume of transactions on the Moscow stock exchange amounted to $\mathrm{Rb}$ 160.5bn (for comparison, in January-February the trade turnover was equal to about $\mathrm{Rb} 147 \mathrm{bn}$ ), but the number of transactions for the period under review has slightly decreased to 26,100 while remaining at a high level (against 30,000 in the previous period) ${ }^{2}$.

Index of the Russian corporate bond market IFX-Cbonds continued to grow, albeit at a lower rate than in the previous month. By the end of March this year its value has increased by 2.1 points (or by $0.6 \%$ ) as compared with the value of the end of the previous month. The weighted average yield of corporate bonds ceased to decline and increased from $8.14 \%$ at the end of February to

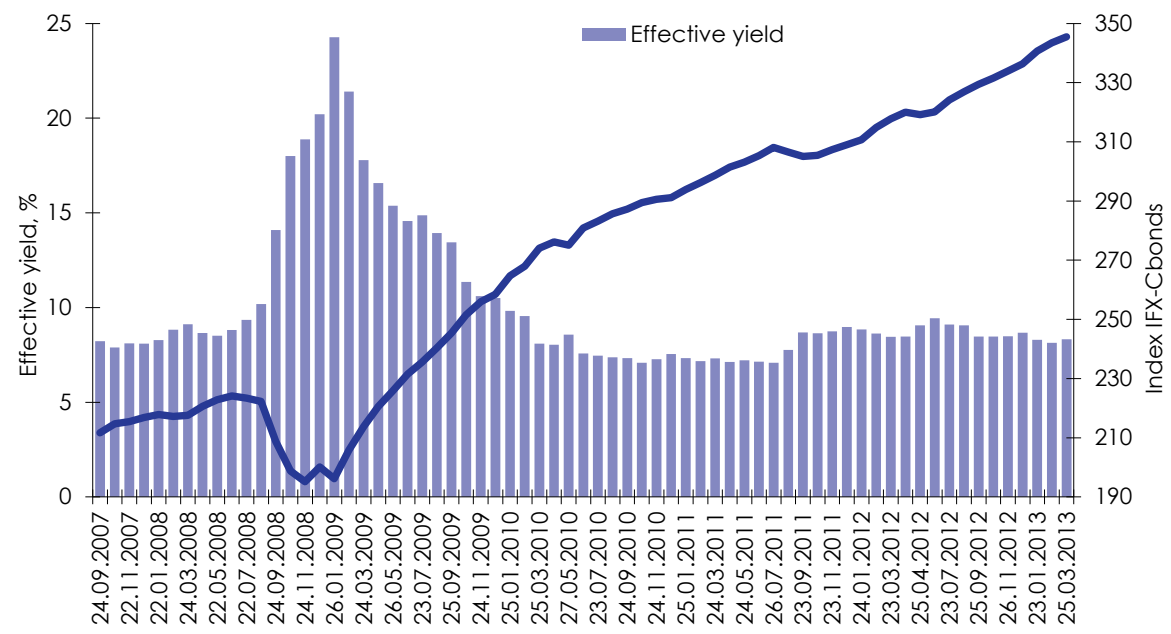

Source: Cbonds information agency data.

Fig. 6. Dynamics of primary of corporate bonds market index and average weighted yield
$8.32 \%$ by the end of March (Fig. 6) ${ }^{3}$.

As was forecasted earlier, the change in the debt market trends occurred in the second half of March primarily because of the deteriorating economic situation in Eurozone and unfavorable oil prices dynamics in early March. The internal situation remained relatively stable, although it is worth noting the weakening of the ruble in late February - early March. Within the month there was observed negative statistics from the Eurozone - the

1 Rusbonds information agency data.

2 Finam investment company data.

3 Cbonds information agency materials. 
growth of unemployment, the decline in GDP and finally, the crisis in Cyprus followed by the downgraded rating of the country. Another reminder of the debt crisis problem was the UK government bond rating downgrading ${ }^{1}$.

Index of portfolio duration corporate bonds after several months of reduction has sharply increased. At the end of March the portfolio duration made 720 days, which is by 168 days longer than at the end of the previous month. Due to the increase in market interest rates a sharp increase in portfolio duration reflects the increase in circulation of bonds in the corporate segment.

The yield of the most liquid bond issues, despite a sharp increase in the average yield was volatile. Herewith, among the industrial and high-tech companies in March there were the most contradictory tendencies, although for most liquid issues of these segments in the previous month a growth was noted. There was instability in the dynamics of bonds yield of energy companies. The decline in the yield was observed in the financial sector, although on average it amounted to only $0.1-0.2$ p.p. $^{2}$

Activity of issuers in terms of registration of new issues of securities has increased as compared with the previous month. Thus, over the period from February 23 to March 25, fifteen issuers have registered 25 bond issues for the total value of $\mathrm{Rb} 118.8 \mathrm{bn}$ (for comparison, from January 24 to February 22, there were 24 series of bonds for the value of $\mathrm{Rb} 82.6 \mathrm{bn}$ ). Major issues were registered by ZAO "VTB 24" (4 series of stock exchange bonds worth Rb 30bn), OAO "Mobile TeleSystems" (also 4 series of stock exchange bonds worth Rb 30bn), ZAO "ING Bank (Eurasia)" (3 series for the amount of $\mathrm{Rb} 15 \mathrm{bn})^{3}$. About half of the registered issues were stock exchange bonds. There were also three debut issues among the registered bonds.

Activity of issuers in terms of the registration of bond issues in March of this year was significantly inferior to the IPO indicators, which is observed in the market very often. Thus, from February 23 to March 25, 26 issuers have placed 40 bond issues totaling to Rb 188.3bn (for comparison, from January 24 to February 22 there were placed 35 bond issues for the amount of Rb 215bn.) (Fig. 7). Stock exchange bonds have made a third of all offered issues. Among the outstanding issues there were several debut bonds, as well as long-term issues: "FOR A Mortgage Agency" managed to raise funds for 32 years, "Rosneft" and "MegaFon Finance" - for 10 years.

From February 23 to March 25, the FFMS of Russia has recognized as invalid 21 issues of bonds due to the failure to place any security, and their state registration was canceled ${ }^{4}$. This record number of canceled issues in the recent years (in recent months - an average of 10-15 issues) is related to changes in plans of the issuers in terms of raising funds from the debt market, as in this case the participants are the major market players (Vnesheconombank, Metalloinvest, VTB Capital Finance, "Razgulay" Group), and it is evident that the demand for such securities would be guaranteed.

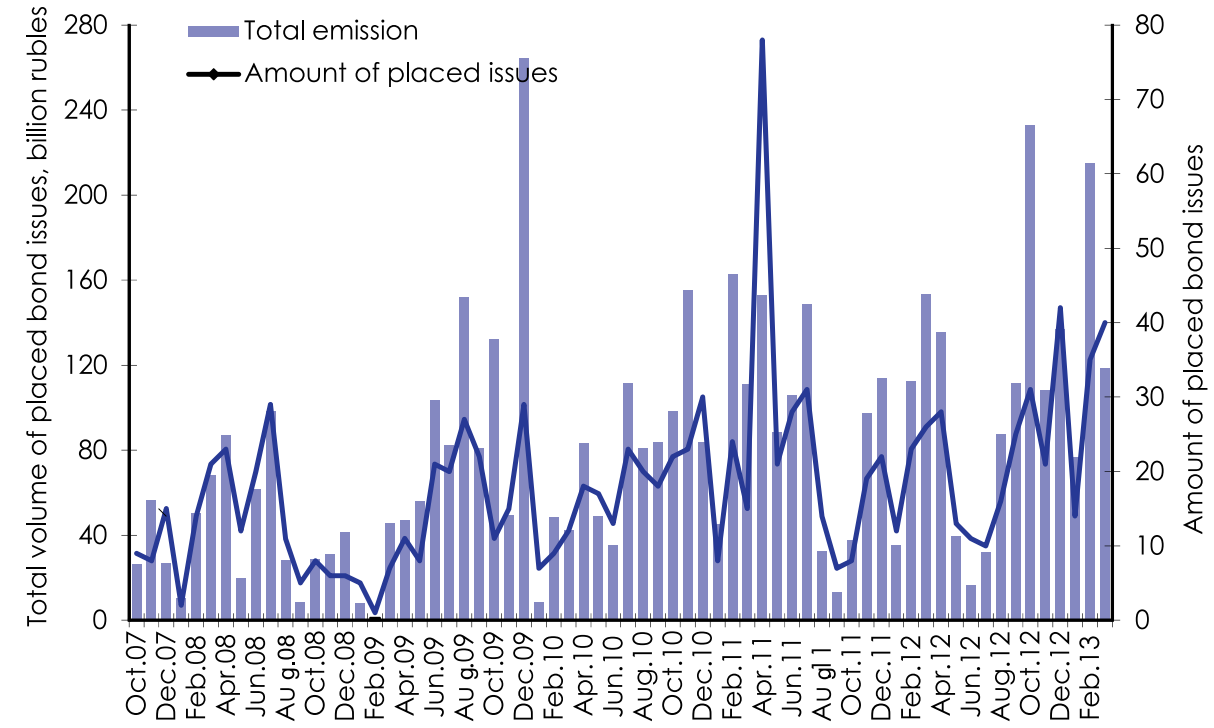

Source: Rusbonds information agency data.

Fig. 7. Dynamics of primary placement of corporate bonds issues, denominated in national currency

\footnotetext{
Cbonds information agency materials.

FInmarket information agency data.

Rusbonds information agency data.

Federal Service for Financial Markets data.
} 
From February 23 to March 25, all 11 issuers have paid out 13 issues of bonds worth Rb 88bn in due time. Like in the previous two months, there were no announcements of technical default. In April 2013, there expected redemption of 16 corporate bond issues totaling to $\mathrm{Rb} 76.0 \mathrm{bn}^{1}$.

The situation with the emitters' performance of their liabilities to the bond holders remains stable. In the period under review only one issuer announced the real default ${ }^{2}$ on coupon yield payment (there were no defaults in the previous period). The face value of bonds redemption and the early redemption of the securities on offer, as well as in the previous months were performed by all issuers in due time, or at least within the framework of technical default ${ }^{3}$.

1 Rusbonds data.

2 When the issuer is unable to pay return to securities holders even in a few days after the due date of liabilities.

3 Cbonds data. 